\title{
Plant Factories as Biopharmac's Production
}

\author{
Marta E Goleniowski ${ }^{1 *}$ and Rosa Cusidó ${ }^{2}$ \\ ${ }^{1}$ Ministry of Science and Technology, Argentina \\ ${ }^{2}$ Laboratori de Fisiologia Vegetal, Universitat de Barcelona, Spain
}

Submission: July 14, 2017; Published: July 26, 2017

*Corresponding author: Marta E Goleniowski, Ministry of Science and Technology, Cordoba, Argentina, Email: mgoleniowski@gmail.com

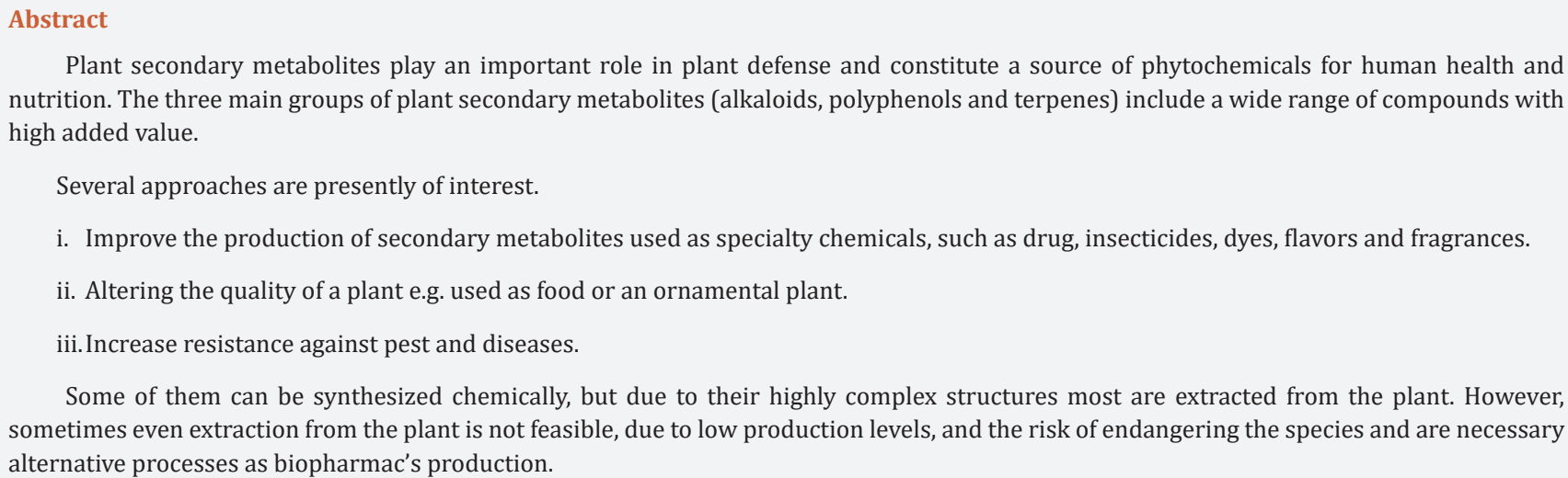

Plant secondary metabolites play an important role in plant defense and constitute a source of phytochemicals for human health and nutrition. The three main groups of plant secondary metabolites (alkaloids, polyphenols and terpenes) include a wide range of compounds with high added value.

Several approaches are presently of interest.

i. Improve the production of secondary metabolites used as specialty chemicals, such as drug, insecticides, dyes, flavors and fragrances.

ii. Altering the quality of a plant e.g. used as food or an ornamental plant

iii.Increase resistance against pest and diseases.

Some of them can be synthesized chemically, but due to their highly complex structures most are extracted from the plant. However, sometimes even extraction from the plant is not feasible, due to low production levels, and the risk of endangering the species and are necessary alternative processes as biopharmac's production.

\section{Biopharmac's Production}

Plant cell and organ cultures constitute a promising platform for the production of numerous valuable secondary compounds. Currently, in vitro culture techniques involve both empirical and rational approaches as suitable strategies to condition high metabolite production and establish competitive plant cell-based bioprocesses. Plant culture techniques using plant cell and organ cultures are promising tools for the production of numerous valuable secondary compounds. Empirical approaches have long been employed for the development and optimization of plant cell-based bioprocesses, focusing on input (cell line, medium, culture parameters, bioreactors, process operations, etc.) and output factors (cell growth, nutrient uptake, productivity, yield, etc.). In addition, a rational approach, taking into account the molecular and cellular basis of metabolic pathways and their regulation, is currently being used.

The biotechnological production of plant secondary metabolites has several advantages over the culture of the whole plant in the field, including:

a. The desired product can be harvested anywhere in the world, maintaining

b. Strict control of production and quality. c. It is not necessary to use herbicides and pesticides.

d. Climate or ecological problems are avoided.

e. Growth cycles are of weeks rather than years.

\section{Anti-Cancer Drugs as Examples of Agent's Product Obtained by biofactories}

Cancer is currently the second principal cause of human mortality after cardiovascular disease, and is a major public health burden [1]. The American Cancer Society has reported that in 2012 there were an estimated 14.1 million cases of cancer diagnosed around the world and 8.2 million cancer deaths. Approximately $60 \%$ of cancer deaths occur in lowand middleincome countries, many of which lack the medical resources and health systems to support the disease burden. It is predicted that by 2030, 21.7 million new cancer cases will provoke 13.0 million deaths [2]. According to the estimation of the US Agency for Healthcare Research and Quality (AHRQ), cancer treatment in the US in 2011 cost $\$ 88.7$ billion, with $11 \%$ for prescription medications

The treatment of cancer is a complex challenge due to the high variability of cancer cells, which favors their growth and 
survival. Standard chemotherapy agents act on all rapidly dividing cells, both normal and cancerous, but other drugs operating in a more targeted way have been developed. Targeted therapies, which interfere with specific molecular targets involved in the growth, progression and spread of cancer, can be grouped according to how they work or what part of the cell they act upon. For example, signal transduction inhibitors can help keep the cancer under control by inhibiting proteins acting as signals for cancer cells to grow. Angiogenesis inhibitors prevent the development of new blood vessels, and thus limit tumor size. Apoptosis-inducing drugs change the proteins within the cancer cells, causing their death. Other targeted cancer therapies involve the immune system, which avoids attacking normal cells in the body by the use of "checkpoints", which are proteins involved in the first steps of the immune response. Cancer cells are able to outwit the immune system by manipulating these checkpoints to avoid being attacked. New plant anti-cancer drugs can interfere with multiple signaling pathways involved in cancer disease, such as cell cycle alteration, and evasion of apoptosis, angiogenesis and metastases.

Although there is a wide range of plant natural products with anti-proliferative activity, only a few plant drugs are included in the Anatomical Therapeutic Chemical (ATC) classification as antineoplastic agents. The successful biotechnological production of phytochemicals with high added value, such as the anticancer compound taxol, shows that plant cell and organ cultures can constitute an alternative to the culture of the whole plant for the production of secondary metabolites with biological activity [3]. These are the vinca alkaloids and their derivatives, podophyllotoxin derivatives, and paclitaxel and its derivatives, as well as camptothecin derivatives Agents [4]. All these compounds have in common a complex chemical structure, a scarce distribution in nature, and a high added value, which has generated considerable interest in finding new sources to meet the market demand and if possible decrease their cost.

In recent years, potent biotechnological systems have been developed to improve the production of plant-derived compounds with biological activity, the so-called "plant cell factories" [5]. These biotechnological platforms are based on plant cell and organ cultures with an optimized capacity to produce target metabolites, matching or enhancing the concentration in the mother plant [6].

Plant cell factories offer several advantages for the production of Plant Secondary Metabolites (PSM) compared to field cultivation:

i) Plant compounds can be produced under controlled conditions independently of climatic fluctuations or soil quality; ii) Cell cultures are free of microbes and insects;

iii) Cell cultures of any plants, whether tropical or alpine, can be established anywhere in the world;

iv) Labor costs can be reduced and productivity improved by the automated control of cell growth and rational regulation of their metabolism;

v) Isolation of the bioactive compounds is more rapid and efficient than extraction from complex whole plants [7].

Moreover, plant cell biofactories are biosustainable systems that normally require a low quantity of the original plants, and therefore avoid endangering wild species in their original habitats. In general, the process involves the isolation of a plant explant, the development of friable calli or hairy roots the establishment of cell line cultures, the optimization of the culture conditions for a high biomass and target compound production, and the scale-up of the process to bioreactor level.

In spite of all these advantages and the extensive study of plant cells for PSM production, few plant cell biofactories have been established on an industrial level. Examples include the production of shikonin and berberin by Mitsui Chemical, Inc., scopolamine by Sumitomo Chemical Co. Ltd., echinacea polysaccharides by Diversa, and the anti-cancer compounds podophyllotoxin by Nippon Oil, and Taxol® by Phyton Biotech. Inc. and Genexol-Samyang Genex [8].

\section{References}

1. WHO Collaborating Centre for Drug Statistics Methodology Norwegian Institute of Public Health.

2. Globocan (2012) Cancer Incidence and Mortality Worldwide.

3. Shoeb M (2006) Anticancer agents from medicinal plants. Bangladesh J Pharmacol 1: 35-41.

4. Shukla, Mehta A (2015) Anti cancer potential of medicinal plants and their phytochemicals: a review. Braz J Bot 38(2): 199-210.

5. Onrubia M, Cusidó RM, Ramirez K, Hernández-Vázquez L, Moyano E (2012) Bioprocessing of plant in vitro systems for the mass production of pharmaceutically important metabolites: paclitaxel and its derivatives. Curr Med Chem 20(7): 880-891.

6. Hussain MS, Fareed S, Ansari S, Rahman MA, Ahmad IZ, et al. (2012) Current approaches toward production of secondary plant metabolites. J Pharm Bioallied Sci 4(1): 10-20.

7. Paek KY, Murthy HN, Jian-Jiang Zhong (2014) Production of Biomass and Bioactive Compounds Using Bioreactor Technology. In: Paek KY, Murthy HN, Zhong JJ (Eds.), Springer, pp. 47-63.

8. Wilson C, and Roberts S (2012) Recent advances towards development and commercialization of plant cell culture processes for the synthesis of biomolecules. Plant Biotechnol J 10(3): 249-268. 
This work is licensed under Creative Commons Attribution 4.0 License

DOI: 10.19080/CTBEB.2017.06.555682

\section{Your next submission with Juniper Publishers} will reach you the below assets

- Quality Editorial service

- Swift Peer Review

- Reprints availability

- E-prints Service

- Manuscript Podcast for convenient understanding

- Global attainment for your research

- Manuscript accessibility in different formats ( Pdf, E-pub, Full Text, Audio)

- Unceasing customer service

Track the below URL for one-step submission https://juniperpublishers.com/online-submission.php 